\title{
NON-EDIBLE SEEDS FOR THE PRODUCTION OF BIODIESEL
}

\author{
Suraj Raj Adhikari ${ }^{1 *}$, Sunil Dutta Baral ${ }^{2}$, Kusum Pokhrel ${ }^{3}$ \\ ${ }^{1}$ Department of Botany, Prithvi Narayan Campus, Tribhuvan University, Pokhara, Nepal \\ ${ }^{2}$ Pokhara University, Pokhara, Kaski \\ ${ }^{3}$ Gogan Secondary School, Pokhara-32, Nepal \\ *For correspondence: adhikarisr@gmail.com
}

\section{ABSTRACT}

The global energy demand is increasing day by day. The consumption of the fuel, as well as the demand, is expected to grow rapidly and use of fossil energy is causing harmful impacts on the environment. Biofuels are attractive alternative to petroleum diesel derived from a variety of feedstocks, vegetable oils, animal fats, and waste cooking oil. They are renewable, non-toxic and biodegradable. At present, biodiesel is mainly produced from many edible oils seed. The extensive use of edible oils for production of biodiesel may lead to food crisis. Therefore, production of biodiesel from non-edible oils is a successful method to overcome all the related problems with edible oils.

Key words: biodiesel, biofuels, Jatropha curcas, non-edible seed, Ricinus communis

\section{INTRODUCTION}

Energy is one of the vital inputs to develop any country. It is predicted that global energy demand will increase by $45 \%$ by 2040 compared to consumption in 2013, resulting in a total $\mathrm{CO}_{2}$ emission increase of $40 \%$ (IEA, 2015). At the same time, achieving the $2{ }^{\circ} \mathrm{C}$ limit on global warming requires new policies to reduce the energy sector's $\mathrm{CO}_{2}$ emissions by replacing traditional and fossil fuels with renewable energies ( IEA, 2015; Faaij, 2006). The types of energy resources available, ways and amount of energy used also indicate the economic development status of a country (World Bank, 1996). In context of Nepal, there is need of sustainable use of alternate kind of renewable energy which are locally available. As Nepal is rich in biodiversity, use of biomass based renewable energy sources should have been promoted. The term biofuels mainly refer to the fuels derived from biomass and is the most abundant source of renewable fuels. Ethanol and methane are examples of biofuels that can be produced from a variable sources of biomass. In general, biofuel consists biodiesel and bioethanol. Recently, biodiesel has received considerable attention as it is non-polluting. There are many examples for non-edible oilseed plant such as Jatropha tree (Jatropha curcas), castor bean seed (Ricinus communis), mahua (Madhuca indica), neem (Azadirachta indica), rubber seed tree (Hevea brasiliensis), tobacco seed (Nicotiana tabacum), rice bran, etc (Demirbas, 2016).

\section{Biodiesel}

The global biodiesel industry is one of the fastest-growing markets. Biodiesel releases less air pollutants since it does not emit sulfur dioxide $\left(\mathrm{SO}_{2}\right)$ by combustion. In comparison to diesel, biodiesels are less toxic and has lower health risk, due to reduced emissions of carcinogenic substances. Since 2004, global biodiesel production increased by 15 -fold, while bioethanol production grew nearly by fourfold (REN21, 2014). The major obstacle for commercialization of biodiesel is its high production cost. Approximately, 70\%-90\% of biodiesel cost is arises from the cost of raw materials (Shikha and Rita, 2012). Using edible oils to produce biodiesel also raises major 
nutritional problem and food crisis in developing countries. In present, energy shortages face to China, like the European Union, United States, and other countries, and promoting the development of biofuels. However, China also faces high future demand for food and feed, and so its bioenergy program must try to strike a balance between food and fuel (Qiu, 2011). There are concerns that biodiesel feedstock may compete with food supply in the long term (Chhetri et al., 2008). While using non-edible oil plants are more economical in comparision to edible plants and are easily available as well as grow in developing countries. Currently, more than $95 \%$ of the world biodiesel is produced from edible oil which is easily available on large scale from the agricultural land. However, continuous and large-scale production of biodiesel from edible oil without proper planning may cause negative impact to the world, such as depletion of food supply leading to economic imbalance (Gui, 2008). The use of non-edible plant oils is very significant because of the great demand for edible oils as food source. Therefore, production of biodiesel from non-edible oils is a successful method to overcome all the related problems with edible oils (Atabani et al., 2013). Nonedible oil plants can be grown in waste lands or poor land, which are not suitable for food crops and the cost of cultivation is much lower because these plants can still sustain reasonably high yield without intensive care (Fatah et al., 2012). Non-edible oil plants are well adapted to arid, semi-arid conditions and require low fertility and moisture demand to grow (Atabani et al., 2013). Biodiesel produced from nonedible vegetable oil has good potential as an alternative diesel fuel. The use of non-edible plant oils when compared with edible plant oils is very significant because of the tremendous demand for edible oils as food, and they are far too expensive to be used as fuel at present
(Mahanta et al., 2006). The advantages of nonedible vegetable oils as a diesel fuel are their higher combustion efficiency, lower sulfur, and higher biodegradability (Shikha and Rita, 2012). This paper aims to focus on different plants producing biodiesel from non-edible vegetable oils.

\section{Jatropha tree (Jatropha curcas)}

Jatropha curcas is a tall bush small tree, up to $5-7 \mathrm{~m}$ tall, belonging to the Euphorbiaceae family. Jatropha curcus is a drought resistant perennial, growing well in marginal and poor soil. Jatropha grows almost anywhere, even on gravelly, sandy and saline soils. It has been planted in several arid regions (Balat and Balat, 2010). Jatropha plant produces seeds with an oil content of around 37\%. Jatropha curcas oil is a non-edible and contains approximately $47.25 \%$ of crude fat, $24.60 \%$ of crude protein, and $5.54 \%$ of moisture content (Akintayo, 2004). The oil fraction of Jatropha curcas consists of both saturated and unsaturated fatty acids. The oil can be combusted as fuel without being refined.

\section{Castor oil plant (Ricinus communis)}

Ricinus communis is commonly known as castor oil plant, belonging to the Euphorbiaceae family. It originates in Africa but it is found in both wild and cultivated states in all the tropical and subtropical countries of the world (Forero, 2004). Ricinus communis is a small woody plant that can reach up to $6 \mathrm{~m}$ height. The comparative advantage of Ricinus communis is that its growing period is much shorter than that of Jatropha curcas (Rajagopal, 2007). Ricinus communis produce highly valuable industrial oil feedstocks because of the very high oil content $(48 \%-60 \%)$ of the seed.

\section{CONCLUSIONS}

Biodiesel is renewable and produced from plant which can be cultivated. It is biodegradable 
and non-toxic. Fossil fuel resources are finite; therefore, there is a continuously growing need for renewable alternatives. Biodiesel is one of the options. The recently rape seed, sunflower seed, Ricinus communis, Jatropha curcas etc are the main raw materials of biodiesel. The major barrier for commercialization of biodiesel is its cost approximately $70 \%-90 \%$ of biodiesel cost is arises from the cost of raw materials (Shikha and Rita, 2012). On the other hand, extensive use of edible food stock may cause highly significant problems such as food crisis in developing countries. Therefore, biodiesel produced from edible vegetable oils is currently not economically feasible. Non-edible oil plants are easily available in developing countries and are very economical comparable to edible plant oils. Therefore, non-edible seed can be used as a suitable for producing biodiesel.

\section{REFERENCES}

Akintaya, E.T. (2004) Characteristics and composition of Parkia biglobbossa and Jatropha curcas oils and cakes. Bioresource Technology. 92(3):307-310.

Atabani, A.E., A.S. Silitonga, H.C. Ong (2013) Nonedible vegetable oils: A critical evaluation of oil extraction, fatty acid compositions, biodiesel production, characteristics, engine performance and emissions production. Renewable and Sustainable Energy Reviews. 18: 211-245.

Balta, M and H. Balta (2010) Progress in biodiesel processing. Applied Energy. 87(6): 1815-1835.

Chhetri, A.B., M.S. Tango, S.M. Budge (2008) Nonedible plant oils as new sources for biodiesel production. International Journal of Molecular Sciences. 9(2): 169-180.

Demirbas, A., A. Bafail, W. Ahmadand, M. Sheikh (2016) Biodiesel production fromnon-edible plant oils. Energy Exploration \& Exploitation. 34(2) :290-318.

Faaij, A.P.C. (2006) Bio-energy in Europe: Changing technology choices. Energy Policy. 34: 322-342.

Fatah, M.A., Farah, H.A. and M.E. Ossman (2012) Production of biodiesel from non-edible oil and effect of blending with diesel on fuel properties. Engineering Science and Technology, an International Journal. 2(4): 583-591.

Forero C.L.B. (2004) Biodiesel from castor oil: A promising fuel for cold weather. Dissertation Submitted to Department of Hydraulic, Fluids and Thermal, Sciences, Francisco de Paula Santander University, Columbia. 12-96

Gui, M.M., K. T. Lee, S. Bhatia (2008) Feasibility of edible oil vs. non-edible oil vs. waste edible oil as biodiesel feedstock. Energy. 33(11): 1646:1653.

IEA (2015) Available online: http://www.iea.org/ newsroom/news/2015/november/worldenergy-outlook-2015.html (accessed on 30 September 2016).

Mahanta, P., S.C. Mishra and Y.S. Kushwah (2006) A comparative study of pongamia and Jatropa curcas oil as diesel substitute. International Energy Journal. 7: 1-11.

Rajagopal, D. (2007) Rethinking current strategies for biofuel production in India. In International conference on linkages in water and energy in developing countries organized by IWMI and FAO, ICRISAT, Hyderabad, India.

Qiu, H., J. Huang, M. V. Keyzer, W. Veen, S. Rozelle, G. Fisher, T. Ermolieva (2011) Biofuel development, food security and the use of marginal land in China. J Environ Qual. 40(4):1058-1067.

REN21 (2014) Renewables 2014 Global Status Report. REN21 Secretariat, Paris. Available at: www. ren21.net/. . ./globalstatusreport.aspx (accessed 18 January 2016).

Shikha, K. and C.Y. Rita (2012) Biodiesel production from non-edible-oils: A review. Journal of Chemical and Pharmaceutical Research.4(9): 4219-4230.

World Bank (1996) Rural Energy and Development, Improving Energy Supplies for 2 Billion People. A World Bank Best Practices Paper. 